\title{
The concept of Ordnungspolitik: rule-based economic policymaking from the perspective of the Freiburg School
}

\author{
Jan Schnellenbach ${ }^{1}$ (D) \\ Received: 16 June 2019 / Accepted: 17 April 2021 \\ (c) The Author(s) 2021
}

\begin{abstract}
Should economic policy be guided by rules? In this paper, we take the perspective of the Freiburg School and trace its argument for rule-based Ordnungspolitik back to the roots of the concept. In doing so, will not offer a comprehensive review of the literature, but argue closely along the works of Walter Eucken, whose contributions are central to understanding the founding generation of the Freiburg School. We argue that not having rules is costly and therefore that the main thrust of the Freiburg approach remains valid. Good empirical arguments can be found for pursuing a rule-based Ordnungspolitik in order to avoid the costs of discretionary policymaking. Furthermore, we argue that reliance on stable rules does not incapacitate democratic decision-making. Rules rely on democratic support, and rule-based Ordnungspolitik also leaves substantial material scope for discretionary democratic decision-making.
\end{abstract}

Keywords Ordnungspolitik · Freiburg school · Economic orders · Economic constitutions

JEL Classifications $\mathrm{B} 15 \cdot \mathrm{B} 25 \cdot \mathrm{B} 41 \cdot \mathrm{H} 11 \cdot \mathrm{P} 48 \cdot \mathrm{P} 50$

\section{Introduction}

Should economic policy be guided by rules? Both the constitutional approach of the Virginia School, as well as the ordoliberal approach of the Freiburg School, generally answer that question in the affirmative. But important differences in the details of the respective arguments lead to the conclusion and some differences emerge in the purposes and designs of rules that guide policy. The aim of the paper at hand, within the context of this special issue of Public Choice, is to outline the particular position of the Freiburg School on rulebased policymaking, and to trace its argument for rule-based Ordnungspolitik back to its historical roots.

In doing so, will not offer a comprehensive review of the entire first generation of the Freiburg School, since that would take us far beyond the scope of a single paper. While

Jan Schnellenbach

jan.schnellenbach@b-tu.de

1 Faculty for Economics, Law and Social Sciences, Chair for Microeconomics, Brandenburg University of Technology, Cottbus, Germany 
different members of the Freiburg School emphasize different issues and arguments, the main thrust of the School's theoretical research program can be extracted from the works of its most prominent proponent, Walter Eucken. Therefore, and because they are essential to understanding the basic arguments of the Freiburg School's founding generation, we will argue closely along the lines laid out in Eucken's work. For a broader overview over the origins of the Freiburg School, see Vanberg (2004) and Kolev (2020). A collection of original texts is assembled in Goldschmidt and Wohlgemuth (2008).

While the German tradition of Ordnungspolitik, which originated in the Freiburg School, bears similarities to the constitutional political economy (CPE) of the Virginia School, important differences also can be found. For example, we will show that the concept of economic order is broad and implies more than just formal constitutional rules. Therefore, Ordnungspolitik as a policy concept that aims at sustaining a functioning market order includes an emphasis on formal rules, but it also includes discretionary policymaking by design. The Freiburg School ventures away from the normative conviction that a functioning market order is desirable and asks which rule-based and discretionary policies are needed to sustain it. It does, however, not ask explicitly what rule improvements could garner unanimous consent, as the Virginia School does.

Important contributions to the relevant literature argue that key elements of Ordnungspolitik in the Freiburg tradition can be reconciled with the modern approach of CPEE and reconstructed as results of constitutional economic reasoning (Feld \& Köhler, 2011; Vanberg, 1988, 2004, 2015). But it is important to reckon that historically, Ordnungspolitik started from a different premise, namely that market competition needs to be sustained by the state and that that function is desirable because a breakdown of market competition has been associated historically with negative outcomes.

In Sect. 2, we will discuss the concept of economic orders and their relationship to systems of (formal) rules. To avoid a common misunderstanding, it is clarified that economic orders are not determined completely by formal rules but have a broader meaning. In Sect. 3, we discuss positive theoretical perspectives on the emergence of and changes in economic orders. Section 4 outlines the normative perspective: Which economic order is considered superior by the Freiburg School, and why? Sect. 5 adopts a more practical perspective and discusses the implementation of a competitive order. Section 6 discusses a critical counterargument stating that rule-based policymaking imposes unwanted restrictions on a democratically elected sovereign. And Sect. 7 discusses whether some of the core assumptions the Freiburg School made in order to justify rule-based Ordnungspolitik remain are applicable to current policy problems. Finally, Sect. 8 concludes.

\section{Economic orders are not (only) systems of rules}

When Walter Eucken (1939, p. 37) discusses economic orders, his analytical starting point has been a variety of organizational forms for economic activity, which he had observed both in time and across places. He illustrates the variety using a number of historical examples for different types of economic organization; in discussing them, he also rejects different established explanations for their emergence. For example, Eucken discusses theories of historical determinism, wherein one type of economic organization necessarily follows another, and presents examples of historical contingencies leading to empirically observable sequences of types of economic organization that were incompatible with historicaldeterminist theories (ibid., p. 53). 
At the same time, Eucken also argues against the concept of styles of economic organization, which would be determined by the specific culture of a region or a country. Again, his criticism is motivated empirically: He discusses historical examples of different places within culturally similar regions being characterized by rather different types of economic organization (Eucken, 1939, pp, 60-61). For instance, Eucken compares German cities in the fifteenth century, wherein differences in relative political power between groups led to differences in economic organization (ibid.), despite very similar cultural backgrounds. With his rejection of the theories of styles of economic organization and of historical determinism, Eucken pits himself against important theories of the German Historical School of Economics.

Instead of searching for historical or cultural determinants of economic organization, Eucken (1939, p. 62) proposes to look directly at the rules that govern economic activity: "Welche Spielregeln herrschen?" is his central question, or "Which are the governing rules of the game?" The rules of the game, on the other hand, are the object of economic policy. They can be either set or at least influenced through political decisions, and are not the result of unalterable historical or sociological laws. The rules of the game are, however, not just formal rules. The rules need to be interpreted and the dominant interpretation of formal rules also is part of the rules of the game.

Furthermore, different market structures may emerge under similar formal rules, but the market structure, exerting a strong influence on the economic behavior of individual producers and consumers, is itself a part of the economic order (Eucken, 1939, p. 218, 1952, p. 22). For example, the same set of formal rules may allow for a competitive oligopoly or a monopoly to emerge. Which of them actually surfaces depends on decisions made by market participants that are not fully determined by the rules, or by pure luck: the outcomes of R\&D projects, for instance. In any case, the actual market structure is to be accounted for as part of the actual economic order. Everything that influences how market participants make decisions is, according to Eucken, part of the economic order-even if it may not explicitly be part of a formal economic constitution.

An economic order, according to Eucken, therefore is more than a formal set of rules, because the actual rules of the game are not entirely and perfectly determined by any set of formal rules. He adopts a telling metaphor when he compares economic orders to elaborate pieces of classical music by Bach, Mozart or Beethoven (Eucken, 1939, p. 202). He points out that all of those musical compositions rely on a fixed system of musical notes and that the composer's creative effort requires, in principle, nothing more than an arrangement or rearrangement of those given notes. Similarly, he argues that empirical economic orders combine different elements from ideal types of economic orders. The ideal types, Eucken (1952, p. 21) later calls them "reine Formen" (pure forms), simply are central planning on the one side, and coordination of individual plans through a competitive price mechanism on the other. Empirically observed orders, Eucken argued, come in a large variety of different actual arrangements, but are basically different combinations of the two pure forms. For example, Eucken (1939) argues that empirically, one will find no uniformly planned economy, and also none that uniformly relies on the price mechanism, but always some kind of mixture of the two.

A concise definition of what an economic order actually encompasses is given by Eucken (1952, p. 23): "Die Wirtschaftsordnung eines Landes besteht in der Gesamtheit der jeweils realisierten Formen, in denen Betriebe und Haushalte miteinander verbunden sind, in denen also der Wirtschaftsprozeß in concreto abläuft.", which can be translated as "The economic order of a country consists of all actually realized forms in which the concrete economic process is embedded and that connect firms and households" (own translation). 
That definition still is somewhat vague, but it clarifies once more that the economic order is about how individual plans are made and coordinated and, moreover, that it would be wrong to equate the economic order with the formal rules that govern an economy. The latter have a more or less immediate impact on the economic order, but they are not the economic order per se.

It is noteworthy that neither that complication, nor the variety of resulting economic orders in reality, led Eucken to advocate a purely descriptive approach to economics, which would serve primarily the purpose of taxonomizing given economic orders. On the contrary, and in strong opposition to the Historical School, his focus is on economic theory to establish a general understanding of the economic and social outcomes associated with observable economic orders. Applied economics, in that sense, involves two steps: Empirically, the task is to discern what kind of economic order we observe in a concrete case; theory is then to be applied to predict the outcomes associated with it (Eucken, 1939, pp. 208-216). Furthermore, theoretical reasoning allows one to predict outcomes of policies that attempt to change an economic order. Economic theory is the prerequisite for economic policy on the level of economic orders.

\section{The origin of economic orders from a positive perspective}

How can the emergence of an economic order be explained? Eucken (1939, pp. 208-216) believed that economic orders normally are not the result of conscious, large-scale design, but rather of processes of evolution. That belief does not imply that deliberate actions do not influence economic orders. On the contrary, Eucken acknowledges that deliberate actions of individuals within an economic order influence the direction of its further evolution. But such deliberate action already is embedded in a given economic order, i.e., an order never is designed from scratch and path-dependence may be important.

When some interest group uses its political clout to secure privileges, the economic order is influenced, e.g., the misuse of the freedom to contract in order to establish a cartel. An economic order is often the sum of many small, deliberate but uncoordinated changes in the system of rules and, in that sense, the economic order as a whole evolves spontaneously. Furthermore, an economic order evolves through the interaction of formal rules and decisions made within a set of formal rules (Eucken, 1939, p. 68). In that respect, Eucken already saw that an economic constitution of formal rules easily may have consequences that were not intended by the rules' authors because individuals often interact with rules creatively, in unanticipated ways.

In his Die Grundlagen der Nationalökonomie (Foundations of Economics), Eucken cites many historical examples to illustrate how a close scrutiny of the details of economic organization and market structure at a given place and time can help in understanding the underlying economic order. In discussing these cases, he frequently also presents fragmentary theories of change in economic orders. For example, Eucken (1939, pp. 213-214) outlines how, in Flemish cities of the thirteenth century, traders of cloth organized and dominated the entire production process of their products, leaving weavers and other craftsmen impoverished. Poverty, in turn, motivated violent protests, and Eucken describes how a change in political power now allowed craftsmen to organize themselves in guilds and, furthermore, how the changed political-economic equilibrium was associated with a change in the economic order, wherein a monopsony of traders and a craftsmen's guild was transformed into a bilateral monopoly. 
Eucken and other ordoliberal thinkers certainly have been aware of the fact that an economic order is subject to endogenous change, and that changes in economic orders themselves are a subject worthy of economic analysis. Eucken's sketches of different historical cases involving changes in the economic order are attempts at understanding processes of institutional change by looking for factors that alter the bargaining powers of various social groups. In that respect, the sketches anticipate later, more sophisticated approaches to the issue.

For example, the research program of North $(1991,1994)$ focuses on institutions as tools that reduce transaction costs, which follow from many different problems such as agency, measurement, or enforcing property rights. But contrary to, e.g., Williamson (1985), who generally models firm-level institutions as efficient responses to those problems, North puts greater emphasis on political-level institutions and acknowledges that a path-dependent evolution of such institutions does not necessarily lead to efficient outcomes.

North (1994, p. 361) argues that weak competition in political markets can lead to the persistence of inefficient institutions, as can the existence of false perceptions of the relative efficiency of alternative institutions (ibid., p. 363). On the other hand, North uses usury laws as an example for an inefficient institution that eventually broke down in early modern Europe, simply because individuals increasingly became creative in circumventing those laws and the transaction costs of effectively prohibiting positive interest rates became prohibitively high themselves (North, 1991, p. 105). And in some cases changes in political bargaining power have been observed to be followed by institutional changes that reduced the discretionary powers of governments, thus securing property rights and paving the way for an expansion of transactions and growth (e.g., North \& Weingast, 1989).

Eucken himself had already been keenly aware of such interactions between political, social and economic institutions. In analyzing them, he coined the term interdependency of orders. That led Eucken (1952, pp.180-184) to discuss different channels of causation of institutional change between political, sociological and economic factors. For example, he argues that a federal political order generally is incompatible with central planning, and that a decision to centralize economic decision-making will lead to an erosion of the federal order. Eucken expects that unchecked monopoly power in a market economy will undermine the rule of law, which in turn has further adverse effects on the efficiency of economic institutions.

A political decision to impose tariffs will, Eucken argues, have a broader impact on the economic order because it increases the market power of firms protected from foreign competition. That argument is rather close to later theories of institutional change that rely on changes in bargaining power between groups as an important trigger, leading Eucken (1952, p. 221) to warn that if they are not analyzed sufficiently, small changes in either the political, the economic or the societal order can be like snowballs that trigger an avalanche, generating and lead to large, unintended consequences in the institutional framework as a whole.

Obviously, Eucken and other early proponents of the Freiburg School could not anticipate later developments in institutional economics and political economy. From the perspective of institutional economics, an efficient change in the economic order or inefficient persistence of a given economic order, both can be plausible outcomes, depending on relative bargaining powers of different interests, as well as on technological progress 
and the degree of rationality underlying political choices. ${ }^{1}$ In some cases, efficient institutional change likewise can be imposed externally by military intervention (Acemoglu et al., 2011).

For obvious reasons, Eucken lacked the formal theoretical apparatus and the quantitative empirical models that modern public choice and political economics bring to bear. But from analyzing historical cases, he reached the unambiguous conclusion that no reason can be found for a Panglossian attitude towards actual economic orders and that any actual economic order is the result of historical and political contingencies, thereby becoming a possible candidate for improvement through purposeful reform. In clear opposition to a Panglossian view, both Eucken and other first-generation members of the Freiburg School, such as Franz Böhm et al. (1937, p. 31), have argued against fatalism and historical determinism and in favor of an economic science whose ultimate rationale should be to guide the purposeful shaping of the economic order.

In sum, the most important similarity between the Freiburg School and modern approaches of public choice and political economics is that the early Ordoliberals already saw the importance of interdependent causal relations between the economic order, social and political institutions. And what is most important, they did not simply assume that political institutions determine the economic order, but that the latter can itself influence the evolution of the former. That insight has been essential for the Freiberg School's normative perspective on the economic order: If the economic order allows for an unfettered accumulation of power, desirable characteristics of the political order come under threat.

\section{Which economic order should rules impose? The normative view}

The claim that pure laissez-faire had failed is the analytical starting point of German Ordoliberalism, resulting from the experience of the Great Depression, but also from the undermining of market competition by openly formed cartels before the Great Depression. Laissez-faire in that context is defined as an order wherein governments provide a legal order, in particular guaranteeing private property rights, but do not actively supervise and influence the evolution of the economic order. In other words, laissez-faire is a regime in which the economic order itself evolves spontaneously within a legal order that protects property rights (Eucken, 1952, pp. 26-54). Again, the importance of distinguishing between formal rules and the actual economic order becomes obvious. Eucken reckons that within a given, formal economic constitution, the unguarded evolution of the economic order can run in an unintended, from a normative point of view, inferior direction.

Consequently, the early ordoliberals criticized the unchecked accumulation of economic power, be it under a central planning agency or with monopoly in a market economy (Eucken, 1939, p. 239). Regarding the negative effects of market power, Eucken (1947, pp. 145-146) takes a broad perspective. He names a failure of the price mechanism to allocate resources efficiently when prices rise above competitive levels. He also makes an argument akin to rent-seeking, and expects that economic power favors and often enforces protectionist policies. And he makes the political-economic point that the abuse of market power can trigger a chain of discretionary interventionist policies, such

\footnotetext{
1 Regarding the latter, also see Denzau and North (1994). For an extreme case of the persistence of inefficient institutions, see Acemoglu et al., (2001).
} 
as price controls, that eventually threaten the working of the price mechanism fundamentally. But finally, Eucken (ibid.) also adds a rather sociological observation, namely that economic power leads to what he calls "Vermassung", a loss of individual freedom and also of individuality with respect to character, lifestyle, or consumption patterns, owing to a dependency on few, powerful businesses and other organizations.

Contrast that with Eucken (1947, p. 147) characterizing a competitive market economy. Here, he argues, the price mechanism facilitates efficient use of resources. The process of competition enhances performance, rather than setting incentives for destructive behavior, as would prevail in a tournament for monopoly power. An order wherein firms and individuals are accustomed to competition, Eucken argues, also will not easily fall for protectionist temptations. And, finally, a competitive order also preserves individual liberty and autonomy.

That simple comparison of two economic orders by Eucken reveals the criteria that underlie his normative thinking. Efficiency in the allocation of resources is important, as is a process of competition that ultimately improves consumer welfare. But in sharp contrast to welfare economic approaches, individual welfare and autonomy both carry normative weight in their own right. They are important not only instrumentally, e.g., because an individual knows best for herself what she requires to maximize her own welfare, but because they are valuable in themselves. Eucken $(1947$, p. 150) sums that conclusion up himself, when he characterizes economics as a science that should help "eine menschenwürdige und funktionsfähige Ordnung zu schaffen", i.e., "to create a humane and functional order" (own translation).

In a similar vein, Franz Böhm (1971, pp. 308-311) warns of the accumulation of political power that occurs when the economic order of a competitive market economy increasingly is crowded out by political interventions and elements of central planning. He argues that the loss of individual autonomy associated with extensive political power over economic planning must seem terrifying, and act as a motivation to seek improvements of the competitive market order instead. What is more important, Böhm (1937, p. 120) explicitly points out that a competitive order will not come about spontaneously, but always depends on the legal framework. Without governments enforcing appropriate rules of the game, a competitive order will neither come into existence, nor be stable once it does.

Economic power is transformed into political power through different channels. The first has been sketched in Sect. 3, where we discussed Eucken's argument that economic power can lead to undue influence in political bargaining processes over institutional changes. That is essentially an early, simple variant of later theories of interest group influence. The second channel is a bit more sophisticated and has been invented by Böhm. The less a firm is exposed to competitive pressures, the greater scope it has to impose self-conceived, private rules that benefit its owners or their transaction partners. By drawing up contract clauses, it creates its own private law. Only a competitive market order ensures that all potential transaction partners can reject a company's self-conceived private law and look for more beneficial conditions elsewhere.

In some cases, attempts to identify and foster a humane economic order also led to somewhat odd policy proposals from individual ordoliberals. For example, Wilhelm Röpke (1944) argued in favor of deliberate promotion of production technologies that supply competitive advantages to small businesses. It is interesting that Röpke's peculiar proposal involves a deliberately discriminatory intervention, in favor of small firms, even if larger firms do not enjoy significant market power. Such a discriminatory approach runs counter to the general, 
rule-based approach Ordoliberalism usually proposes, but Röpke deems it necessary in that specific case to restrict production to a small and therefore, in his opinion humane, scale.

The claim that an economic order ought to serve different objectives clearly can lead to contradictions if they need to be traded off against one another. In the example above, Röpke puts great emphasis on what he believes to be a necessary characteristic of humane societies, namely, the organization of economic activity in small firms rather than large organizations in which the single individual is anonymous and interchangeable. A different ordoliberal economist, with less of a conservative Christian background than Röpke, could emphasize efficiency to a much greater extent, arguing in favor of exploiting economies of scale in larger firms. Given our discussion thus far, it therefore is not entirely clear which goals an ordoliberal, rule-based policy should serve.

Eucken and other members of the Freiburg School, such as Franz Böhm, distinguish themselves from other ordoliberals, like Röpke, by assigning unambiguous priority to securing competition as the material goal of economic policy and implementing a non-discriminatory, privilege-free order to do so (Vanberg, 2004, p. 2). However, that recommendation does not simply reflect a personal preference, e.g., for economic efficiency and against having a more humane order (or what some people may believe to be a humane order), but an empirically testable claim that a competitive order that puts restraints on individual power simultaneously helps to achieve both an efficient and a humane economic order.

That claim can be made only on the level of general rules. A welfare economist micromanaging an economy always will see tradeoffs between the two objectives, as Röpke likewise did. Owing to his (at least implicit) claim that some sizes of firms optimally balances efficiency concerns with the concern of having a humane order, firm size itself becomes a policy objective. A policymaker would have to leave the level of general, rule-based policies and engage in micro-managing the economy, as a neoclassical welfare maximizer would do.

But on the level of rules, one can even claim that Röpke's optimal intervention rests on a misperception because one cannot pursue isolated, prima facie optimal interventions into the market process. The reason reveals a categorical difference between Ordnungspolitik and Prozeßpolitik, between rule-level policymaking and interventions into the market process, as perceived by Eucken. The former sets (or at least influences) the rules of the game, the latter attempts to steer the economy towards specific desired results by direct intervention. But, as Eucken argues, attempts at Prozeßpolitik often lead to spirals of intervention. If policymakers distort one margin, private-sector adaption often will lead to unintended consequences, which beg another intervention, and so on. Prozeßpolitik, argues Eucken, itself threatens the stability of a market order and leads to a crowding out of competitive forces by central planning (Vanberg, 2004, p. 2). However noble the underlying intentions may be, attempts to directly intervene into the market process, according to Eucken, risk severe damage to the competitive economic order as a whole and through the interdependency of orders also to the political and societal order. Therefore, economic policymaking always should aim at a rational design of the rules that shape (albeit sometimes indirectly) the economic order and to make sure that that order is a competitive one - because only then is the stability of an order that also is humane secured. 


\section{Rule-based Ordnungspolitik: a more practical perspective}

Eucken was well aware of some issues of the political economy of providing economic policy expertise. He argued that such expertise could well be used for problematic purposes and that even well-intended policy efforts, for example, those directed at reducing unemployment, could be abused to further the goals of special interest groups (Eucken, 1947, p. 138). Eucken clearly is not taking the same position adopted later by welfare economics, advocating for economics to give counsel to hypothetical, ideal governments. The Freiburg ordoliberals want to improve actual economic policy and they are aware that in order to do so, they will need to account for the problems of actual policymaking processes. They also were aware of the problem that a rational, rule-based set of policies may not be easy to implement. Eucken (1952, p. 219) even argued that times of crisis might be the most important windows of opportunity wherein fundamental reforms of the economic order could find the necessary political support.

The first core element of the Freiberg School's political program is competition policy. Perfect competition is the ideal, a market structure wherein nobody, neither on the supply nor on the demand side, has significant market power and wherein, therefore, the price mechanism leads to an efficient allocation of resources. Perfect competition is associated with Leistungswettbewerb, a form of competition in which suppliers' resources are directed towards improving their goods or lowering their prices, in contrast to more destructive forms of competition, such as actively sabotaging the efforts of rivals in order to gain market power. In a world where rule-based competition policy prohibits firms from harvesting excessive monopoly rents, such destructive efforts appear irrational (Eucken, 1952, p. 247). Such a competition policy needs to be predictable; it needs to define clear criteria for a regulatory body to intervene and, for example, prohibit mergers of some companies. That rule-based approach also is a self-commitment of governments to refrain from unwarranted interventions into the market process itself: The less discretionary leeway they have, the less likely are abuses of the power in the conduct of competition policy, e.g., in order to support special interest groups.

Therefore, when we discuss Ordnungspolitik as rule-based policy, the discussion relates to at least two levels. One level is the policy directed at the economic order, which market participants experience as the rules of the game. Such policies can come as negative, formal rules addressed at market participants and also as political efforts to create the necessary conditions for a competitive order (Eucken, 1952, p. 255). The second level, however, political self-restraint, implies that constitutional rules restricting the scope of government interventions also are an element of Ordnungspolitik. Governments need to be prohibited from implementing policies that endanger the proper functioning of the price mechanism, with everything that entails: no inflationary monetary policies, no protectionism, no favoring of market incumbents, no subsidies that prevent the exit of insolvent firms, no direct price controls, and many more (Ibid.). On the second level, Ordnungspolitik likewise always entails the task of looking for rules that ensure governmental self-restraint regarding such undesired policies (also see Böhm, 1966).

Eucken (1952, pp. 254-303) is well-known for having established a number of principles that he believed should guide Ordnungspolitik and that sum up in a more systematic way what governments should and should not do. His konstituierende Prinzipien (constitutive principles) need, in his own view, to be followed in order to establish the conditions for a competitive economic order to be functional at all. They are: 
1. Stable money: Eucken argues that stable money is a prerequisite for the price mechanism to work, and he argues that that goal may require a monetary order that leaves little leeway for the monetary authorities to engage in discretionary policymaking. A monetary constitution that grants technocrats independence and commits them to a stable inflation rate target would, in his view, not be sufficient. Instead, a rule that ensures stable and predictable rates of money supply growth could be desirable (Eucken, 1952, p. 259). ${ }^{2}$

2. Open markets: Eucken was convinced that a lesson to be learned from economic history is that closure of markets facilitates the emergence of cartels and generally secures market power. That obviously is true for some cases of market closure, such as tariffs or regulatory burdens that deter entrants. It often also is true of a denial of market exit, if, for example, inefficient incumbents receive subsidies and thereby deter Schumpeterian processes of creative destruction. ${ }^{3}$ His focus on openness even led Eucken to be critical of patent laws, which he suspected to guard inefficient market power (Eucken, 1952, pp. 268-269).

3. Secure private property rights: Anticipating some later developments in the new institutional economics, Eucken saw the importance of having secure private property rights. He substantiated his argument with inter alia the responsibility and competence that goes along with owning a property right in some resource. If the owner is fully accountable, he will seek the best possible use (ibid., p. 271). Eucken accompanies the argument in favor of secure property rights immediately with the importance of competition. Only in a competitive order, can we expect the power associated with property reliably to be held in check (ibid., p. 275).

4. Freedom to contract: This point seems a straightforward requirement for competition in a market order, but again, Eucken adds some words of caution. Freedom to contract needs to be embedded in a competitive order. Naming freedom to contract as a necessary requirement for competition and at the same time the stability of a competitive order as necessary for freedom to contract to yield positive outcomes may seem paradox at first. But it is important to see that economic policy has the explicit task of resolving the paradox by seeing that the freedom to contract is not used to build cartels or reduce competition in other forms (ibid., pp. 277-279).

5. Accountability: One component of the principle of accountability is straightforward; individuals are accountable for their own actions. If those actions lead to profits or other benefits or to losses should not matter and, in particular, channels that allow the externalization of losses should be closed. The second component may be less obvious. Suppose that a government regulates firms heavily. If such regulations affects their competitiveness adversely, the losses accrue to shareholders, not to the political decision-makers (ibid., p. 282). The principle of accountability therefore also leads to some skepticism regarding the legitimacy of regulatory interventions in general.

6. Consistency of economic policy: Eucken considers it important that individuals and firms are capable of making informed decisions over longer time horizons. Such predictability, he argues, in particularly important for stimulating investment. Thus, economic policy should be foreseeable and stable.

\footnotetext{
${ }^{2}$ For a more extensive discussion of Ordoliberalism and monetary policy, also see Feld et al., (2021) and Köhler and Vanberg (2015).

${ }^{3}$ See, e.g., modern Schumpeterian growth theory, as in Aghion et al., (2014).
} 
The constitutive principles are amended by a set of so-called regulatory principles. Eucken (1952, pp. 291-303) was well aware of the reality of market imperfections that cannot be cured by setting the rules for a competitive order alone. Natural monopolies and externalities are such cases, but he also argues that some degree of income redistribution will be necessary. Thus, the Ordoliberals have from early on reckoned that in some cases, efficiency demands direct interventions into market outcomes. But those interventions themselves are rule-based; clearly defined conditions should trigger them. ${ }^{4}$

All of the constitutive principles can and should be implemented by some form of rulebased policy. A quantitative monetary policy rule controlling money supply is possible, as are constitutional rules that prohibit governments from engaging in protectionist policies. Constitutional rules of non-discrimination guaranteeing that the price mechanism is not distorted by discretionary subsidies to privileged firms likewise can be conceived. Private property rights can be secured by rules that limit the sizes of permissible tax burdens. It is important to see that such rules constrain discretion and that they do not determine economic outcomes. They define a playing field and rules of the game for both private producers and consumers acting in ordinary markets and for the political process itself.

An important issue that also needs to be addressed is enforcement. The paradox that rules limiting government need to be enforced by government itself cannot be escaped. The Freiberg School's founding generation carried with them a normative idea of what they called a "strong state", i.e., a state that is not receptive to offers from special interest groups, but restricts itself to playing the role of a neutral referee. They have, however, not developed a coherent proposal as to how politicians can be bound to that normative ideal. Even though the enforcement problem remains unsolved, the idea of a strong state has drawn some criticism claiming that Ordoliberalism inherently is authoritarian. ${ }^{5}$

\section{Rule-based policy-making and the democratic process}

It is intuitively plausible that a stable, competitive order facilitates the type of productive competition that is envisaged by Eucken as an ideal, thereby steering the economy to serve the broad interests of consumers. Something that may be less plausible is the role remaining for democratic decision-making, when the discretionary decision-making power of governments effectively is constrained. Not surprisingly, some critics of ordoliberal thinking claim that the rule-based approach reflects a thinking that is skeptical of democracy and that wants to restrain the polity to acting as a servant of an efficient market process.

The standard counterargument is that such critics of the ordoliberal position ignore that the analytical starting point for Eucken and others are the costs of not complying with their proposed principles. The historical root of the ordoliberal argument was, at the time, fresh experience of a breakdown of the economic order during the Great Depression and of Germany's political order thereafter. In their interpretation, those orders broke down as a result primarily of laissez-faire allowing market power to accumulate and of undue and inefficient discretionary policymaking that both failed to stabilize the economy and eroded the competitive order in consequence of governmental collusion with powerful special interests.

\footnotetext{
4 A referee has pointed out that the list of constitutive principles bears some resemblance to the items in the Economic Freedom of the World Index. I have, however, not found any indication that the authors of the EFW Index have been inspired directly by Eucken.

${ }^{5}$ For an in-depth discussion of the issue, see Köhler and Nientiedt (2021).
} 
To assume that laissez-faire leads to an undue accumulation of power by special interests is not, as it may at first seem, a logical fallacy. It is a hypothesis about the emergence of power from an unchecked laissez-faire framework: Competition needs to be secured actively by the government, e.g., through active antitrust policy enforcement banning cartels and collusion. If such policies are not pursued, then, so the ordoliberal hypothesis goes, the laissez-faire order will erode itself, because market participants are allowed to become too powerful by evading competition.

The ordoliberal interpretation is pre- and post-Second World War period was not a unique historical experience, but that erosion of the competitive order associated with excessive discretionary policy is a permanent danger. The argument is therefore that only a state detached from serving special interest groups in a discretionary fashion is a strong state that can support the stability of desired orders. That is an empirical argument and it should be debated as such-we will return to this point in Sect. 7.

As soon as one leaves the abstract level of discussion on rule-based policymaking and discusses concrete measures, more margins of democratic decision-making appear. The first-generation members of the Freiburg School did not develop an explicit political economy of finding and recommending a specific constitutional order for a given time and place. That gap in the theory may have contributed to a common misconception of Ordoliberalism as a doctrinal ideology that demands enforcing a fixed set of rules, specified in detail in the writings of, by now, long-deceased Freiburg School members. Clearly, that interpretation is a misrepresentation. Rules need to be negotiated and every concrete rule poses concrete tradeoffs. A political decision made along such lines reflects a society's heterogeneous values und preferences.

Economic policy proposals, from an ordoliberal or any other school, will in practice serve only as inputs into real-world democratic processes. For example, a constitutional rule that limits the scope of taxation in order to protect private property rights will in practice be implemented only after broad democratic deliberations. Those discussions could concern the allowable total tax burden or the permissible structure of a tax scheduleare, for instance, regressive income taxes acceptable? Many other features of such a tax rule need to be traded off against others. ${ }^{6}$ Or consider the problem of patent law raised by Eucken, who emphasizes the danger that patents will reduce competition and serve primarily as legal underpinnings of monopoly power. From a different perspective, one obviously could argue that patent law creates incentives to invest more resources in research and development and thus increases the velocity of Schumpeterian creative destruction. Again, a conflict arises between two possible objectives that can be resolved only through democratic deliberation and decision-making. One objectively correct rule for economic policymaking towards innovation policy is not available and political value judgments must be considered.

Furthermore, and little recognized in economics so far, theoretical and policy uncertainty are widespread even on issues like international trade or minimum wage laws, which have been studied for many years. Generally, no perfect ex ante knowledge is available about the actual functioning of an economic policy rule. And different individuals arrive at different conclusions about the effects that a rule eventually will have. Ideally, a process of thorough democratic deliberation amongst individuals who treat one another as "natural equals" (Levy \& Peart, 2020) facilitates an informed judgment about alternative rules.

${ }^{6}$ See, e.g., the proposal for constitutional tax reform by Brennan and Buchanan (1980). 
Individuals share their dispersed knowledge and a more complete, informed picture of proposed rules emerges (Vanberg \& Buchanan, 1989). Of course, in reality, conflicts of theory and conflicts of interest overlap; individuals therefore have different motives than to let themselves be persuaded by the better argument (Schnellenbach \& Schubert, 2015). But even if the process is not ideal, a period of democratic deliberation can improve the informational basis of a decision on rules.

The criticism that rule-based policy-making renders democratic processes irrelevant thus is grossly misleading. Rule proposals for economic policy are merely inputs into the process of democratic deliberation, intended to solve well-specified problems. A rulebased approach to economic policy is not a substitute for democratic procedure, but relies heavily on it. $^{7}$

\section{Is rule-based Ordnungspolitik still called for?}

We have seen so far that the Freiburg School advanced plausible arguments in favor of rule-based policymaking. We likewise have seen that recent arguments that rule-based policymaking is in conflict with the principles of an open democracy are not very convincing. Historically, the catastrophic economic collapse of the Great Depression and the even more catastrophic political collapse of the Weimar democracy in Germany led the members of the Freiburg School to advocate Ordnungspolitik. But are other, less spectacular examples still to be found wherein rules could be useful in limiting the scope of discretionary policymaking?

Four examples can illustrate the point that, from a modern perspective, the basic claims made by the first generation of Ordoliberals remain rather robust. The examples do not include the established fields of rule-based economic policymaking, such as the adoption of fiscal rules or the delegation of monetary policy to independent central banks. Rather, they are intended to illustrate that the slow erosion of the competitive market order, that members of the Freiburg School wanted to prevent by introducing suitable rules, is still a threat to be reckoned with.

Consider, for example, the argument that individual autonomy is worthy of protection by appropriate rules. A long-standing debate in behavioral economics questions whether individuals are capable of correctly estimating ex ante the utilities associated with the choices they are going to make. ${ }^{8}$ Individuals often fail to predict expected utility accurately and therefore make choices they later regret. One could argue that such errors simply are part of the human condition, or one could propose "expert" help in making better choices. The latter approach is associated with a relatively novel strand of research on behavioral public economics, which looks for policy interventions that supposedly improve welfare by driving individuals to make choices that maximize actual, rather than falsely predicted utility. A popular aspect of that school of thought is the literature on so-called nudging, which is supposed to improve decision-making by using deliberately designed decision frames that manipulate individuals into choosing with a higher probability the alternative that a supposedly benevolent paternalist planner considers superior (e.g., Sunstein \& Thaler, 2003).

\footnotetext{
7 Note, however, that Eucken has been rather wary of the danger that special interest groups dominate the democratic process; see Nientiedt and Köhler (2016).

${ }^{8}$ For instance, Frey and Stutzer (2007) and the discussion in Schnellenbach (2019).
} 
But fundamental empirical problems are associated with such an approach. First of all, it does not work reliably owing to an epistemic problem that is well-known: Individuals seldom know what exactly satisfies the preferences of other individuals and therefore the probability is high that interventions produce results that are not helpful (Rebonato, 2012). Systematic biases also emerge. For example, in experiments, individuals who are supposed to guide the choices of others are much stricter (e.g., when it comes to a healthy diet) than they are when they consider their own choices. The result can be over-regulation of individual behavior and a loss of autonomy.

Another empirical result from experimental research shows that individuals who are subjected to paternalist interventions exhibit a positive willingness to pay to be able to make their own choices (Lusk et al. 2014; Kragh Pedersen et al., 2012). From a psychological perspective, the empirically motivated self-determination theory states that individuals generally seek autonomy in determining their own goals and become more satisfied when they can pursue them themselves. Self-determination is seen as a basic human need (Deci \& Ryan, 2000, 2012).

We therefore observe, on one side, well-intentioned attempts to improve individual welfare by systematically overriding consumer sovereignty. Such attempts can come in the form of proliferating consumer protection laws or in the form of nudges and other manipulative exploitations of behavioral mechanisms. On the other side, we also observe an empirically well-documented preference for individual autonomy. A good reason to value one's own autonomy highly is that individuals do not know today how their own preferences will look tomorrow. If I do not know today how my preferred consumption patterns will be tomorrow, I have little reason to favor restraining my consumer sovereignty (Sugden, 2010).

A contractarian argument can then be made that individuals seek opportunity and demand an institutional order that expands and safeguards their choice sets from government intervention (Sugden, 2010). That argument is indeed very close to the ordoliberal argument that a competitive economic order with an undistorted price mechanism and free of arbitrary interventions into voluntary transactions should be the general objective of rule-based policymaking. And the empirical evidence hinting at the importance of autonomy in choice also aligns with the ordoliberal stance of preserving a humane economic order, as discussed above. The preservation of consumer sovereignty by adopting appropriate rules can be supported by arguments from the modern literature on behaviorally motivated policy interventions.

As a second example, consider the costs of discretionary interventions into the competitive order. Prima facie, it appears that modern market economies are extremely resilient. It is safe to say that most governments do not pursue the implementation of Eucken's constitutive principles as their main policy objective. Instead, discretionary interventions into market processes are ubiquitous-but we still observe long-run growth, a reasonable degree of economic freedom, and relatively stable democracies in most advanced nations. The danger of a complete collapse and self-destruction of a competitive market order seems to be not as acute as the first generation of Ordoliberals have argued under the fresh impression of the Great Depression and rise of National Socialism, Fascism and Communism.

But although modern market economies and democracies seem to be rather resilient and can sustain high levels of productivity and social welfare even with major discretionary interventions and massive public spending; the welfare losses imposed, for example, by rent-seeking effort still are non-negligible. Even though illegal, potentially scandalous types of rent seeking typically are not very pervasive in open democracies (Hillman and 
Ursprung (2016), many costly rent-seeking activities are evident. Attempts arbitrarily to deter newcomers from market entry regulatorily occur on a regular basis (consider the troubles Uber has in entering many heavily regulated European taxi markets), and some countries have returned to the ancient practice of defending their home market with tariffs.

The overall effect of rent seeking on welfare in advanced economies is notoriously difficult to estimate, in particular owing to unavailable data and the interval bounding the existing estimates of rent-seeking costs as a fraction of GDP rangrd from almost zero to a quarter of GDP (Del Rosal, 2011). But one has to take into account that some of those costs, such as the costs of foregone innovations caused by entry barriers, escape quantification more or less completely. In any case, rent seeking never is a productive activity and a rule-based policy that reduces rent seeking and secures the openness of markets can be expected to have positive effects, even if it is not necessary to prevent complete systemic failure of a market economy, or even an extreme accumulation of economic power that eventually threatens the functioning of democracy itself.

As a third example, consider the effects of a very generous welfare state with high replacement rates. It has been argued that in such a setting, a previously existing work ethic may be crowded out permanently (Lindbeck, 1995). Indeed, some survey data align with that hypothesis. Relying on data from the World Values Survey, Lindbeck and Nyberg (2006) found that a more extensive welfare state tends to be accompanied by weaker selfreported work ethics. ${ }^{9}$ As far as a functioning market economy also depends on social norms and attitudes that are compatible with such an order, a danger therefore arises that very generous welfare states crowd out those very norms. The example shows that the interdependency of orders, as understood by Eucken, also can apply to informal rules and is not limited to the interactions of formal institutions.

As a final example, consider the problem of political selection. In the absence of rulebased politics, selection becomes extremely important. Once a politician is in office, the means to control her political decisions are rather imperfect. Parliamentary majorities often avoid the risks of snap elections and thus support governments, even if their policy choices run against the preferences of a significant number of members of the majority fractions. Referendums, if available at all, often are costly to organize. The more imperfect are the means of political control, the more important is the selection of politicians whose preferences align with those of a majority of voters. But what if a significant number of voters rewards trivial characteristics such as a candidate's good looks (Berggren et al., 2017)? And that is only one example of what political scientists call valence.

A behavioral perspective on political decision-making processes shows that voters' choices can be driven by all kinds of considerations that have nothing to do with the material outcomes of political alternatives (Schnellenbach \& Schubert, 2015). If both the selection process of political representatives and the means of ex post control are highly imperfect, rule-based policymaking can be seen as a useful commitment device that prevents excesses possibly following the accidental selection of incompetent or eccentric representatives. Modern approaches to political economics tend to confirm the imperfections of democratic procedures and highlight the importance of rule-based checks on discretionary government power. Limiting power by adopting appropriate rules is vital not only on markets in order to sustain a competitive economic order, but also in politics, where competition always is much more indirect an incomplete.

\footnotetext{
${ }^{9}$ Heinemann (2008) found the result to be robust when accounting for macroeconomic influences that were omitted from the original analysis.
} 


\section{Conclusions}

Some of the analytical starting points of the Freiburg School of economics seem peculiar from a modern perspective. In particular, market economies and modern democracies could be more robust and less vulnerable than assumed by the School's first-generation members. Under their experiences with the Great Depression and the rise of National Socialism, they argued that only a close-knit system of rules could secure the desired stability of the economic and political orders in the long run. That conclusion appears not to be the case.

Nevertheless, we argue that not having rules is costly and, hence, that the main thrust of the Freiburg approach remains valid. Good empirical arguments can be identified for pursuing a rule-based Ordnungspolitik in order to avoid the costs of discretionary public policymaking. Furthermore, we argue that relying on stable rules does not imply incapacitating democratic decision-making. Rules rely on democratic support and rule-based Ordnungspolitik also leaves substantial material scope for discretionary democratic decision-making.

While we have seen differences between the Freiburg School and the Virginia School in terms of motivating emphasis on rules, and also in terms of laying different normative foundations for rules, we also have seen overlaps. It is therefore an interesting question as to what extent Buchanan himself may have been inspired by the earlier works of Eucken and other members of the Freiburg School. It is well-established that that a main influence on Buchanan's thinking has been the "Old" Chicago School (Levy \& Peart, 2020). As individuals, in particular Frank Knight and Henry Simons (Köhler \& Kolev, 2013), who held very similar positions on the role of the state as the Ordoliberals did, played an important role in influencing Buchanan. But more importantly, it is also argued that Friedrich von Hayek was an important bridge for ideas and topics between Freiburg und Chicago, by maintaining personal relations both to the Freiburg School, and to "Old" Chicago figures like Simons (Köhler \& Kolev, 2013; Kolev, 2021).

Thus, there is reason to believe that the similarities in thinking that exist between the Freiburg School and the Virginia School are not entirely accidental. Certainly, Buchanan himself has emphasized repeatedly his own affinity to the tradition of thinking about orders, which both the Freiburg School and the Old Chicago School represent (Kolev, 2018).

Funding Open Access funding enabled and organized by Projekt DEAL.

Open Access This article is licensed under a Creative Commons Attribution 4.0 International License, which permits use, sharing, adaptation, distribution and reproduction in any medium or format, as long as you give appropriate credit to the original author(s) and the source, provide a link to the Creative Commons licence, and indicate if changes were made. The images or other third party material in this article are included in the article's Creative Commons licence, unless indicated otherwise in a credit line to the material. If material is not included in the article's Creative Commons licence and your intended use is not permitted by statutory regulation or exceeds the permitted use, you will need to obtain permission directly from the copyright holder. To view a copy of this licence, visit http://creativecommons.org/licenses/by/4.0/. 


\section{References}

Acemoglu, D., Cantoni, D., Johnson, S., \& Robinson, J. A. (2011). The consequences of radical reform: The French revolution. American Economic Review, 101(7), 3286-3307

Acemoglu, D., Johnson, S., \& Robinson, J. A. (2001). The colonial origins of comparative development: An empirical investigation. American Economic Review, 91(5), 1369-1401

Aghion, P., Agcigit, U., \& Howitt, P. (2014). What do we learn from Schumpeterian growth theory? In P. Aghion \& S. N. Durlauf (Eds.), Handbook of economic growth. (Vol. 2, pp. 515-563). Elsevier.

Berggren, N., Jordahl, H., \& Poutvaara, P. (2017). The right look: Conservative politicians look better and voters reward it. Journal of Public Economics, 146, 79-86

Böhm, F. (1937). Die Ordnung der Wirtschaft als geschichtliche Aufgabe und rechtsschöpferische Leistung. Kohlhammer.

Böhm, F. (1966). Privatrechtsgesellschaft und Marktwirtschaft. Ordo Jahrbuch für die Ordnung von Wirtschaft und Gesellschaft, 17, 75-151

Böhm, F. (1971). Freiheit in Ordnung in der Marktwirtschaft. Reprinted in N. Goldschmidt and M. Wohlgemuth (2008), pp. 299-312.

Böhm, F., Eucken, W. and Großmann-Doerth, H. (1936). Unsere Aufgabe. Reprinted in N. Goldschmidt and M. Wohlgemuth (2008), pp. 27-41.

Brennan, B., \& Buchanan, J. M. (1980). The power to tax. The analytical foundations of a fiscal constitution. Cambridge University Press.

Deci, E. L., \& Ryan, R. M. (2000). The 'what' and 'why' of goal pursuits: Human needs and the self-determination of behavior. Psychological Inquiry, 11, 227-268

Deci, E. L., \& Ryan, R. M. (2012). Motivation, personality and development within embedded social contexts: An overview of self-determination theory. In R. M. Ryan (Ed.), Oxford handbook of human motivation. (pp. 85-107). Oxford University Press.

Del Rosal, I. (2011). The empirical measurement of rent-seeking costs. Journal of Economic Surveys, 25(2), 298-325

Denzau, A. T., \& North, D. C. (1994). Shared mental models: Ideologies and institutions. Kyklos, 47(1), 3-31

Eucken, W. (1939). Grundlagen der Nationalökonomie. Fischer.

Eucken, W. (1947). Über die zweifache wirtschaftspolitische Aufgabe der Nationalökonomie. Reprinted in N. Goldschmidt and M. Wohlgemuth (2008), pp. 133-154.

Eucken, W. (1952). Grundsätze der Wirtschaftspolitik. (7th ed.). Mohr Siebeck.

Feld, L. P., \& Köhler, E. A. (2011). Ist die Ordnungsökonomik zukunftsfähig? Zeitschrift für Wirtschaftsund Unternehmensethik, 12, 173-195

Feld, L.P., Köhler, E.A. and Nientiedt, D. (2021). Die Europäische Währungsunion aus traditioneller und moderner ordnungsökonomischer Perspektive. Ordo Jahrbuch für die Ordnung von Wirtschaft und Gesellschaft 69, forthcoming.

Frey, B. S., \& Stutzer, A. (2007). What happiness research can tell us about self-control problems and utility misprediction. In B. S. Frey \& A. Stutzer (Eds.), Economics and psychology. A promising new crossdisciplinary field. (pp. 169-196). Cambridge: MIT Press.

Goldschmidt, N., \& Wohlgemuth, M. (Eds.). (2008). Grundtexte zur Freiburger Tradition der Ordnungsökonomik. Untersuchungen zur Ordnungstheorie und Ordnungspolitik 50. Mohr Siebeck.

Heinemann, F. (2008). Is the welfare state self-destructive? A study of government benefit morale. Kyklos, $61,237-257$

Hillman, A. L., \& Ursprung, H. (2016). Where are the rent-seekers? Constitutional Political Economy, 27(2), 124-141

Köhler, E. A., \& Kolev, S. (2013). The conjoint quest for a liberal positive program: "Old Chicago", Freiburg, and Hayek. In S. J. Peart \& D. M. Levy (Eds.), F.A. Hayek and the modern economy. (pp. 211-228). Palgrave Macmillan.

Köhler, E. A., \& Nientiedt, D. (2021). Was Walter Eucken a proponent of authoritarian liberalism? Public Choice. https://doi.org/10.1007/s11127-021-00876-z

Köhler, E. A., \& Vanberg, V. J. (2015). The constitutionalization of money: A constitutional economics perspective. In L. H. White, V. J. Vanberg, \& E. A. Köhler (Eds.), Renewing the search for a monetary constitution. (pp. 59-103). CATO Institute.

Kolev, S. (2018). James Buchanan and the "new economics of order" research program. In R. E. Wagner (Ed.), James M. Buchanan. A theorist of political economy and social philosophy. (pp. 85-108). Palgrave Macmillan. 
Kolev, S. (2020). Ordoliberalism's embeddedness in the neoliberalisms of the 1930s and 1940s. In M. Dold \& T. Krieger (Eds.), Ordoliberalism and European economic policy: Between Realpolitik and economic utopia. (pp. 23-38). Routledge.

Kolev, S. (2021). When liberty presupposes order: F.A. Hayek's learning ordoliberalism. Freiburg Discussion Papers on Constitutional Economics 21/02, Freiburg: Walter Eucken Institut.

Levy, D. M., \& Peart, S. (2020). Towards and economics of natural equals. A documentary history of the Virginia School. Cambridge University Press.

Lindbeck, A. (1995). Hazardous welfare-state dynamics. American Economic Review (P\&P), 85, 9-15

Lindbeck, A., \& Nyberg, S. (2006). Raising children to work hard: Altruism, work norms and social insurance. Quarterly Journal of Economics, 121, 1473-1503

Lusk, J. L., Marette, S., \& Norwood, F. B. (2014). The paternalist meets his match. Applied Economic Perspectives and Policy, 36, 61-108

Nientiedt, D., \& Köhler, E. A. (2016). Liberalism and democracy. A comparative reading of Eucken and Hayek. Cambridge Journal of Economics, 40, 1743-1760

North, D. C. (1991). Institutions. Journal of Economic Perspectives, 5(1), 97-112

North, D. C. (1994). Economic performance through time. American Economic Review, 84(3), 359-368

North, D. C., \& Weingast, B. R. (1989). Constitutions and commitment: The evolution of institutions governing public choice in seventeenth-century England. Journal of Economic History, 49(4), 803-832

Pedersen, S. K., Koch, A. K., \& Nafziger, J. (2014). Who wants paternalism? Economics Bulletin, 66, S147-S166

Rebonato, R. (2012). Taking liberties. A critical examination of libertarian paternalism. Palgrave Macmillan.

Röpke, W. (1944). Civitas Humana. Grundfragen der Gesellschafts- und Wirtschaftsreform. Rentsch.

Schnellenbach, J. (2019). Evolving hierarchical preferences and behavioral economic policies. Public Choice, 178, 31-52

Schnellenbach, J., \& Schubert, C. (2015). Behavioral political economy. European Journal of Political Economy, 40, 395-417

Sugden, R. (2010). Opportunity as mutual advantage. Economics \& Philosophy, 26, 47-68

Sunstein, C. R., \& Thaler, R. H. (2003). Libertarian paternalism is not an oxymoron. University of Chicago Law Review, 70, 1159-1202

Vanberg, V.J. (1988). 'Ordnungstheorie' as constitutional economics. The German conception of a 'social market economy'. Ordo - Jahrbuch für die Ordnung von Wirtschaft und Gesellschaft 39: 17-31.

Vanberg, V.J. (2004). The Freiburg School: Walter Eucken and Ordoliberalism. Freiburg Discussion Papers on Constitutional Economics 04/11. Freiburg: Walter Eucken Institut.

Vanberg, V. J. (2015). Ordoliberalism, Ordnungspolitik and the reason of rules. European Review of International Studies, 25, 27-36

Vanberg, V. J., \& Buchanan, J. M. (1989). Interests and theories in constitutional choice. Journal of Theoretical Politics, 1, 49-62

Williamson, O. (1985). The economic institutions of capitalism. The Free Press.

Publisher's Note Springer Nature remains neutral with regard to jurisdictional claims in published maps and institutional affiliations. 